ДО ПИТАННЯ ПРО СИСТЕМУ ВИЩОЇ ОСВІТИ АВСТРАЛІЇ

\title{
TO THE PROBLEM OF AUSTRALIAN HIGHER EDUCATION SYSTEM
}

у статті розглядаються деякі аспекти розвитку вищої освіти Австралії. Метою статті є з'ясування особливостей виникнення, розвитку та системи вищої освіти Австралії. Встановлено, що вища освіта країни бере початок у 1850 р., коли було відкрито перший університет у м. Сідней. До початку Першої світової війни кожен итат країни мав свій університет. Акцентовано увагу на тому, що з початку свого існування австралійські університети мали світську орієнтацію та незалежність від релігійних установ. Зазначено, що бурхливий розвиток вищої освіти почався із середини $X X$ $\mathrm{cm}$. Розглянуто послідовність виникнення нових типів навчальних закладів. Акцентовано увагу на процесі реформування освіти наприкінці 80x рр. та керівній ролі уряду країни в цьому процесі. Висвітлено організаційно-педагогічну структуру університетів. Виявлено, що якість навчання в цілому визначається за допомогою акредитації закладів освіти й навчальних програм. Установлено, що якість вищої освіти Австралії здійснює організація під назвою TEQSA. Розглянуто сім необхідних пунктів щодо оцінювання якості надання освіти. Зазначено, що вища освіта в Австралії $\epsilon$ багатоступеневою, та розглянуто основні академічні кваліфікації у країні. Розглянуто систему прийому до закладів вищої освіти та вимоги університетів до майбутніх студентів. Крім того, акцентовано увагу на дотриманні правила регіонального прийому до закладів вищої освіти. Розглянуто деякі аспекти інтернаціоналізації вищої освіти та співробітництво Австралії та Азіатсько-Тихоокеанського регіону у сфрері освіти. Надано статистику щодо кількості студентів, їх працевлаштування, доходів країни від надання освітніх послуг іноземним громадянам тощо. Зроблено висновок про те, що вищій освіті Австралії, яка базувалась на принципах британської системи, притаманні висока якість викладання, інтернаціоналізація, гуманізація освіти, самостійність студентів та значний акцент на наукові дослідження

Ключові слова: вища освіта, Австралія, історія та розвиток вищої освіти, реформування, акредитація, інтернаціоналізація.
The article deals with some aspects of Australia's higher education development. The purpose of the article is to find out the peculiarities of the emergence, development and higher education system of Australia. It was found that the country's higher education started in 1850, when the first university in Sydney was opened. Before the outbreak of World War I, each state had its own university. Attention is drawn to the fact that Australian universities have had a secular orientation and independence from religious institutions since their inception. It is noted that the rapid development of higher education began in the middle of $X X$ century. The sequence of emergence of new types of educational institutions is considered. The emphasis is done on the process of education reform in the late 1980s, and the leading role of the country's government in this process. The organizational and pedagogical structure of universities is highlighted. It is revealed that the quality of education is generally determined by accreditation of educational institutions and training programs. The quality of Australia's higher education is provided by an organization called TEQSA. The seven necessary points for assessing the quality of education are discussed. It is noted that higher education in Australia is multistage and the main academic qualifications in the country are discussed. The system of admission to higher education institutions and the requirements of universities for prospective students are considered. attention is paid to adherence to the rules of regional admission to higher education institutions. Some aspects of internationalization of higher education and the cooperation of Australia and the Asia-Pacific region in the field of education are considered. Statistics on the number of students, their employment, income of the country from the provision of educational services to foreign citizens is provided. It is concluded that higher education in Australia is based on the principles of the British system, and it has high teaching quality, internationalization, humanization of education, student independence and a strong emphasis on research.

Key words: higher education, Australia, history and development of higher education, reforms, accreditation, internationalization. економічного університету

імені Семена Кузнеця
Постановка проблеми в загальному вигляді. Вища освіта Австралії - це доволі молода, але потужна структура, яка пройшла складний шлях за 170 р. свого існування. Зараз Австралія займає одне з провідних місць у наданні освітніх послуг, як для своїх громадян, так і для представників багатьох інших країн. Вища освіта Австралії привертає увагу через високу якість підготовки спеціалістів, мультикультурність та індивідуалізацію навчального процесу. Одним із найбільш пріоритетних напрямків державної політики Австралії протягом останніх десятиліть стала освіта. Тому досвід розвитку вищої освіти Австралії може бути цікавим для України, яка наразі йде шляхом реформування освіти та входження до світового освітнього співтовариства.
Аналіз останніх досліджень і публікацій. Вивчення досвіду вищої освіти Австралії з кожним роком знаходить все більше відображення в публікаціях учених різних країн. Деякі аспекти педагогіки Австралії на пострадянському просторі розглядали у своїх роботах І. Балицька, А. Волкова, В. Гарова, С. Голерова, К. Ейхбаум, І. Майорова, О. Мосолова, О. Пулінець, С. Строкова. Важливо зазначити, що систему вищої освіти Австралії вітчизняні вчені практично не вивчали. Тому було вирішено почати дослідження австралійської науково-педагогічної літератури щодо історії розвитку вищої освіти Австралії та особливостей національної підготовки спеціалістів. 
Виділення не вирішених раніше частин загальної проблеми. Комплексних наукових досліджень, предметом яких $€$ система вищої освіти Австралії. нами не було виявлено.

Мета статті. 3 огляду на актуальність проблеми метою статті $€$ 3'ясування особливостей розвитку та системи вищої освіти Австралії.

Виклад основного матеріалу. Розвиток вищої освіти в Австралії пов'язаний з діяльністю англійських колоністів, які потрапили у країну в 1788 р. Ідея університету була завезена до країни разом із парламентом і поліцією, мовою і традиціями. Цей колоніальний спадок мав британський характер. В результаті бурхливого розвитку економіки й культурного життя вже в середині XIX ст. були відкриті перші університети - в м. Сідней (1850 р.) та в м.Мельбурн (1853 р.). Пізніше було створено ще два університети, у м. Аделаїда (1874 р.) та на о. Тасманія (1890р.) [6]. Основними характерними рисами розвитку університетів цього періоду були: виключно британська орієнтація освіти щодо організації та змісту навчання в університетах; їх повна ізольованість один від одного, а також нечисленність контингентів, яка налічувала кілька десятків студентів.

Із цього часу почала активно фрормуватися система вищої освіти країни. «Образ» і традиції австралійського університету були сорормовані у другій половині XIX ст. із часу свого заснування австралійські університети сприйняли та почали активно впроваджувати прогресивні тенденції освіти, які виникли в цей період в низці європейських країн. Так, жінки отримали право навчатися в університеті вже в 1874 р., стала запроваджуватись вечірня та заочна вища освіта, у змісті навчання перевагу віддавали професійній і прикладній орієнтації в порівнянні 3 пануванням «вільних мистецтв» в університетах Європи. Інженерні курси навчання виділили в окремий напрямок університетської освіти вже 60x роках XIX ст. I3 самого початку свого існування австралійські університети мали світську орієнтацію та незалежність від релігійних установ, що значно відрізняло австралійські університети від університетів Європи і Сполучених Штатів Америки [6].

Університети Австралії були центрами освіти й культурного життя у своїх штатах. В університетах готували вчителів середніх шкіл та фрахівців із різних галузей відповідно до потреб економічного розвитку країни. У першій половині $\mathrm{XX}$ ст. австралійські університети підтримували тісний взаємозв'язок 3 англійськими університетами, які командирували до Австралії свої педагогічні кадри, а також здійснювали післядипломну підготовку австралійських випускників [3].

Бурхливий розвиток вищої освіти почався з середини XX ст. У період із 1946 р. по 1980 р. у країні відкрилось 13 нових університетів, чисель- ність студентів вищих навчальних закладів зросла в 6 разів, збільшившись із 25,5 тис. до 163 тис. Серед нових університетів були технологічні університети, які створювалися в передмістях головних міст штатів та отримали в Австралії назву «приміські університети». Наступний вид університетів, так звані регіональні університети, організовувались у віддалених місцевостях.

У середині XX ст. на австралійську вищу освіту великий вплив мали американські дослідницькі університети, в результаті чого вперше було виділено кошти на організацію наукових досліджень у рамках університетів, було запроваджено навчання на ступінь доктора фрілософії, створено національний університет Австралії 1946 р., орієнтований на наукові дослідження.

У 60-х роках виник новий тип навчальних закладів - коледжі підвищеного навчання (Colleges of Advanced Education), які здійснюють підготовку середнього технічного персоналу у сорері державного управління та для промислового сектору.

На початку 70x років в Австралії з'явилися коледжі технічної й безперервної освіти (Colleges of Technical and Further Education). Ці навчальні заклади мали широку профресійну орієнтацію, а також спеціалізацію в галузі освіти дорослих.

Таким чином, у другій половині XX ст. в Австралії у сорері після середньої освіти сорормувалася бінарна система навчання: 3 одного боку - університети, з іншого - система коледжів, яка охоплювала коледжі підвищеного навчання, коледжі технічної й безперервної освіти, які займали проміжну позицію між середніми школами та університетами. Однак у результаті збільшення попиту на університетську освіту вже до кінця 70-х років 70\% усіх коледжів підвищеного навчання мали післядипломні рівні підготовки (крім присудження ступенів доктора наук), що фрактично зробило їх вищими навчальними закладами.

Наслідуючи британську академічну традицію, австралійські університети розвивалися автономно. Із середини XX ст. бюджет університетів не витримував різкого збільшення чисельності студентів. Виходом із ситуації стало введення федеральних програм університетського фрінансування. В результаті цього значно посилився вплив федерального управління на діяльність університетів. Але до початку 80x рр. роль університетів зводилась лише до розвитку інтелектуального та духовного потенціалу суспільства. Університети досить довго залишалися осторонь від вирішення найважливіших економічних завдань загальнодержавного значення. У зв'язку з цим із середини 80-х років федеральний уряд провів низку реформ у сорері освіти, зокрема університетської, спрямованих на збільшення внеску вищих навчальних закладів у вирішення соціальних економічних проблем країни. Програма реформ торкнулася різних 
сторін діяльності університетів: наукових досліджень, фрінансування, прийому до вищих навчальних закладів, організації і змісту навчання тощо.

Провідну роль в управлінні вищою освітою відіграють уряди штатів. Усі університети країни, крім Національного університету Австралії, засновані парламентами своїх штатів. Національний університет Австралії заснований завдяки санкції фредерального парламенту.

Кожен штат має своє міністерство освіти на чолі з міністром, на якого покладено головну відповідальність за стан і розвиток освіти на всіх рівнях у межах даної адміністративної одиниці. На фредеральному рівні після ряду реорганізацій управління вищою освітою здійснює міністерство працевлаштування, освіти й підготовки кадрів, засноване в 1987 р., Рада з питань вищої освіти, Австралійський комітет віце-канцлерів тощо. До сфери компетенції цих установ й організацій входить вирішення проблем фрінансування закладів вищої освіти, а також розробка політики в галузі вищої освіти в загальнонаціональному масштабі.

Структура університетів Австралії фрормувалася історично. Так, шість найстаріших університетів штатів мають у своїй основі фракультети, які мають у собі декілька департаментів, а також коледжі. До складу університетів, створених у 60х роках, входять так звані школи, що представляють собою вищі навчальні заклади, які спеціалізуються в будь-якій галузі знання і мають, як правило, післядипломні рівні підготовки. На відміну від фракультетів, які входять до складу університетів, школи мають більш незалежний статус. Особливу структуру має Національний університет Австралії, до складу якого входять фракультети та дослідні школи, а також дослідницькі центри й лабораторії, консультативні центри та центри безперервної освіти, дослідні інститути.

В університетах головним керівним органом $€$ сенат або рада університету, яку очолює канцлер - це, як правило, один із видатних громадських діячів штату. До складу сенату входять виборні представники від викладачів, студентів, а також випускники цього університету, члени уряду штату, видатні бізнесмени. Реальним керівником університету є віце-канцлер, який у найстаріших університетах обирається на все життя. Всією академічної діяльністю управляє академічна рада університету.

Якість навчання в цілому визначається за допомогою акредитації закладів освіти й навчальних програм. Однак серед університетів існує історично сорормована ієрархія, на чолі якої знаходяться найстаріші Заклади вищої освіти, створені ще в другій половині XIX ст. й на початку XX ст.: це університети міст Сідней, Мельбурн, Аделаїда, штатів Тасманія, Квінсленд і Західна Австралія, до яких належить з точки зору престижності й Націо- нальний університет Австралії. Університети цього рангу є центрами підготовки науково-педагогічних і дослідницьких кадрів для інших Закладів вищої освіти країни, в них зосереджені найсильніші наукові школи, сконцентровані основні фундаментальні дослідження.

На нижчому щаблі стоять університети технічного профрілю, створені в 40-50-і рр., які спеціалізувалися на підготовці висококваліфрікованих інженерів і дослідників у галузі новітніх напрямків науки й техніки. Створені в 60-70-х рр., приміські та регіональні університети місцевого значення розташовуються на найнижчому щаблі академічної престижності, проте їх соціальна значущість оцінюється дуже високо, оскільки вони чуйно реагують на запити й потреби місцевої влади та жителів штату щодо вищої освіті, надаючи можливість навчання по найрізноманітнішому спектру навчальних програм.

У той же час слід зазначити, що політика федерального уряду в галузі структурної реорганізації системи вищої освіти спрямована на нівелювання ієрархії університетів і коледжів 3 метою досягнення високого рівня якості навчання в усіх Закладах вищої освіти. Використовуючи фрінансові важелі, фредеральний уряд надає підтримку Закладам вищої освіти, які досягли високого рівня навчання, незалежно від їх статусу. Реформа передбачає у процесі структурної уніфрікації університетів і коледжів ввести їх диверсифікацію за профілем навчання, цільовими установками, напрямком наукових досліджень тощо.

В Австралії існують два види програм вищої освіти:

а) ті, які пропонуються інститутами (державними і приватними) та промисловістю для професійної освіти;

б) курси вищої освіти, які пропонується університетами.

Університети Австралії мають міжнародну репутацію закладів освіти, які надають високоякісні освітні послуги та проводять наукові дослідження світового рівня завдяки академічному складу спеціалістів, яких набирають на роботу як з Австралії, так і з усього світу.

Вища освіта в Австралії є багатоступінчастою. Університети й інші заклади вищої освіти надають студентам програми, які направлені на отримання ступеня бакалавра та низки інших наукових ступенів. Деякі університети також пропонують скорочені курси для студентів останнього курсу за корпоративними програмами. Зараз у країні налічується 1313776 студентів, причому 25,1\% із них - закордонні [8]. Основою вищої освіти Австралії є бакалавріат. Ступінь бакалавра присвоюють студентам, які пройшли Зрічний курс навчання, хоча існують деякі спеціальності зі строком підготовки бакалавра від чотирьох до шести років. Диплом бака- 
лавра австралійського університету в усіх країнах вважається показником повної вищої освіти. Якщо студент провчиться додатковий рік або протягом трьох років проявить неабиякі здібності, він може претендувати на диплом бакалавра з відзнакою.

Магістерська програма освоюється за 2 роки. В системі вищої освіти Австралії налічується три види магістерських програм: професійна спеціалізація; профресійна спеціалізація із захистом наукової роботи; дослідницька робота з подальшим захистом виконаної наукової роботи.

Найвищою академічною кваліфрікацією є ступінь доктора наук. В Австралії існують два типи докторських програм: перший із них аналогічний нашій аспірантурі, другий націлений на практичне застосування результатів досліджень. Ступінь доктора наук присуджується після глибокого вивчення теоретичного курсу й виконання науково-дослідної роботи. Все разом, в тому числі й дослідження, займає 3 роки [1].

Особливістю австралійської системи вищої освіти є розвинений сектор дистанційних програм: 10 із кожних 100 австралійських студентів отримують знання дистанційно [1].

Усього в Австралії нараховується 40 університетів, два з них є приватними. У країні існує ще чотири автономних організації, які надають вищу освіту, та близько 150 неавтономних організацій. Ці організації акредитовані в урядах штатів та територій. Австралійські університети мають фріліали в Малайзії, Сінгапурі, Південній Африці та В'єтнамі. Найбільш престижні вищі навчальні заклади Австралії складають «Групу восьми», дипломи яких високо цінуються серед роботодавців. До об'єднання увійшли наступні університети:

- Мельбурнський, який займає 36 місце у світовому університетському рейтингу та спеціалізується на викладанні природничих і медичних наук;

- Квінслендський. До складу університету входять інститути мозку, інститут молекулярно-біологічних наук, а також інститут нанотехнологій, інститут біоінженерії;

- Австралійський національний університет, основними напрямками роботи якого $€$ астрофрізика й астрономія. Найбільша обсерваторія Австралії заснована на базі Дослідницької школи, створеної при університеті;

- Сіднейський, який входить до першої двадцятки кращих вищих закладів освіти світу. Основними фракультетами університету є гуманітарний, соціальний та природничий, медичний та фракультет інформаційних технологій;

- університет Нового Південного Уельсу, в якому вивчають машинобудування й витончені мистецтва, право й антропогенне середовище;

- університет Західної Австралії, в якому студенти опановують знання з обчислювальної технології, математики, стоматології тощо;
- університет Монаш, що має власні центри досліджень газовидобутку і стовбурових клітин;

- університет Аделаїди, в якому навчаються майбутні нафтовики, машинобудівники й хіміки, ветеринари і психологи.

Всі організації Австралії, які надають вищу освіту, мають діючі механізми забезпечення якості їх курсів та освітніх послуг, які відповідають міжнародним стандартам. Австралійські університети, згідно із законодавством, засновані як автономні організації. Вищим органом їх управління $€$ рада Сенату. Приватні організації, які надають вищу освіту, повинні бути зареєстровані та мати програми навчання, затвердженні урядом країни.

В австралійських університетах не існує вступних іспитів. Отримання місця студента в університеті після закінчення школи цілком залежить від результату випускних іспитів, які відображаються у свідоцтві про закінчення школи (High School Certificate). Назва сертифрікату може варіюватися в залежності від штату або території, але всі вони мають однакову силу для австрійських університетів. Право вступу до закладів вищої освіти мають випускники повної середньої школи. Шкільний період навчання в Австралії включає 6 років початкової та 6 років середньої школи. Обов'язковий період навчання - з 6 до 16 р., збігається із закінченням неповної середньої школи. Поряд із загальноосвітньою школою, на середньому рівні діють і професійні школи (3-4 роки навчання), а також спеціальні професійні школи. Охоплення середньою освітою відповідної вікової групи становить 87\% [2, с. 136].

Необхідно зазначити, що кожен штат має повну автономію щодо видів і назв документів про закінчення повної середньої школи, змісту навчальних програм, а також вимог до випускних іспитів. Фактично із середини 60х років середня освіта в кожному штаті знаходиться у стані перманентної ресрорми. Структура навчальної програми досить мобільна, її завдання - забезпечити спеціалізацію учня в будь-якому обраному напрямку, особливо на останньому щаблі середньої школи.

До обов'язкових вимог у кожному штаті входить лише загальна кількість предметів, яке варіюється від 4 до 7, а також загальна кількість так званих залікових одиниць. У низці випадків може особливо обумовлюватись мінімальний обсяг підготовки 3 математики, природничих наук й іноземних мов. У навчальному плані курси, як правило, діляться на головні, відповідні напрямку спеціалізації, і другорядні, обсяг яких визначається в одиницях.

Регулювання академічних стандартів, за повної свободи визначення змісту навчання, забезпечується системою акредитації та реєстрації навчальних курсів у середній школі. Акредитація навчальних курсів за категорією вище простої реєстрації. Вона визначає курси по рангах. Наприклад, для 
того, щоб бути прийнятим до університету, необхідно мати певну кількість залікових одиниць за курси так званого третього рівня 3 великим обсягом теоретичної підготовки.

У більшості штатів програми навчання для двох останніх років середньої школи складаються учнями спеціально, виходячи з подальших планів на навчання, тому що кількість залікових одиниць і ранг курсів для вступу до закладів вищої освіти в кожному штаті визначається окремо. У програми для тих, хто бажає продовжити навчання в університетах, як правило, включені такі предмети, як математика, природничі науки, англійська мова, суспільні науки, історія, географія. У деяких штатах документ про закінчення повної середньої школи видається без випускних іспитів.

В Австралії в цілому дотримуються правила регіонального прийому до закладів вищої освіти. Узв'язкузцим кожен закладвищоїосвітипред'являє свої вимоги до прийому студентів, спираючись на діючу в цьому штаті систему оцінки знань випускників школи. В цілому, для вступу до університету або коледжу підвищеного навчання необхідно мати документ про закінчення повної середньої школи (12 років навчання), в технічні коледжі приймаються особи 3 неповною середньою освітою.

Усі випускники школи, які бажають вступити до закладу вищої освіти, наприкінці 12го року навчання повинні взяти участь у тестуванні здібностей, яке централізовано проводиться відповідною службою. Результати тестування передаються до обраного закладу вищої освіти, адміністрація якого приймає конкретне рішення про зарахування на навчання. При відборі студентів ураховуються профріль підготовки й рівень поточної успішності учнів, шкільні характеристики. Варто зауважити, що для дорослого контингенту абітурієнтів вимоги значно знижені, і в разі відсутності достатньої академічної підготовки для них на базі університету організовуються підготовчі курси. В технічні коледжі прийом здійснюється на базі як неповної, так і повної середньої освіти, при цьому конкурс оцінок відсутній.

Система профресійної освіти в Австралії спрямована на забезпечення студентів необхідними економіці спеціальностями, які визначають роботодавці. Студенти отримують кваліфікацію тільки після складання випускних іспитів. На сьогодні в державній системі профресійної освіти нараховується приблизно 1,7 млн. студентів, 3 них 418 тис. навчаються в рамках державної програми стимулювання навчання.

Урядом Австралії було затверджено Національну стратегію із працевлаштування, в рамках якої уряд співпрацює із провідними промисловими групами з метою створення програм навчання, які відображають поточні та майбутні потреби промисловості. Уряд країни також заохочує програми підвищення кваліфрікації для осіб старшого віку. Наприклад, за даними за 2010 р., 6 млн. осіб у віці 15-64 років, що складає 44\% осіб цього віку, отримали додаткову освіту. Слід зауважити, що значна частина осіб, які здобувають другу вищу освіту, перебувають у віковій групі осіб середнього віку (25-54 років) [5].

Значна частина осіб отримувала додаткову освіту у практичній галузі. Наприклад, 25\% осіб отримували спеціальність менеджера 3 торгівлі, велика частина цієї ж групи (3/4) отримувала додаткову освіту в закладах вищої освіти. В цілому, протягом 1990x рр. частка населення Австралії у віці 25-64 роки, які мають профресійну або вищу освіту, зросла з 46,5\% до 51\%. У грудні 2014 р. ця цифрра досягла 53,3\% [5].

Уряд Австралії грає керівну роль у визначенні, а також просуванні національних стандартів $\mathrm{i}$ пріоритетів для студентів. Ключовими цілями $€$ впровадження та використання передових найвищих стандартів освіти завдяки національній узгодженості та відповідальності, підвищення якості навчання, гарантія безпеки системи навчання та забезпечення стандартів рівності доступу до освіти.

Якість вищої освіти Австралії здійснює організація під назвою TEQSA (нова Рамка стандартів вищої освіти). Законом про TEQSA у 2011 р. було заснувано TEQSA та затверджено нормативну базу для австралійської вищої освіти, які прийшли на зміну Агенції якості австралійських університетів (AUQA) та низці національних протоколів, раніше прийнятих Радою австралійських урядів (COAG). Спочатку робота TEQSA була зосереджена на регулюванні та якості освіти, зараз ії повноваження звужені, в першу чергу, до регулюючої фрункції.

Існують сім необхідних пунктів щодо оцінювання якості надання освіти:

1) кількісні показники залучення студентів;

2) навчальне середовище;

3) викладання;

4) науково-дослідницька робота;

5) забезпечення інституційної якості, управління та підзвітності;

6) представництво;

7) управління інформацією.

Вони охоплюють усі аспекти діяльності університету, включаючи основні види діяльності - освіти та дослідження. Крім цього, велика увага приділяється захисту студентів, у тому числі студентівдослідників. Це значить, що навчальний процес спрямований на ефективну навчальну практику від вступу абітурієнта до університету до отримання ужестудентомнавчальногоступеню.Щостосується дослідницької роботи, то увага приділяється ґрунтовному та етичному проведенню досліджень [7].

Федеральний уряд Австралії несе первинну відповідальність за орінансування сектору вищої 
освіти. Крім цього, на уряди штатів і територій покладена відповідальність за розвиток сектора профресійного навчання. Отже, система освіти й підготовки кадрів в Австралії є предметом постійного контролю 3 боку уряду, промисловості та інших профресійних об'єднань, підтримки й поліпшення її вже високих стандартів. Гарантією високих стандартів освіти в Австралії є тісна взаємодія між системою освіти й урядом Австралії, а також урядами штатів і територій. Завдяки цій взаємодії у країні функціонує національно сумісна система стандартів, яка стосується затвердження, перевірки, зовнішнього моніторингу та незалежного аудиту якості освітніх послуг [2, с. 139].

Австралія $€$ однією зі світових країн-лідерів, які надають освітні послуги для іноземних студентів, в тому числі вивчення англійської мови. Більш ніж 400 тис. студентів з більше ніж 200 країн світу отримують освіту в Австралії щороку. Із них більше 300 тис. осіб навчаються на короткострокових курсах.

Сектор міжнародної освіти Австралії є найбільшим експортним сектором послуг, який приносить в економіку країни 11,7 млрд. дол. За даними за 2006-2007 рр., Австралія була кращим вибором для іноземних студентів із багатьох країн, а також третім найпопулярнішим англомовним напрямком для навчання іноземних студентів.

Як експортна стаття, освіта іде на рівні продажу пшениці і дає Австралії доходів більше, ніж традиційна торгівля вовною. За прогнозами спеціалістів, до 2025 р. цей сектор економіки принесе до бюджету держави не менше ніж 38 млрд. австралійських доларів і вийде на перше місце за прибутковістю серед індустрії сервісу, залишаючи позаду навіть туризм [1]. У 2020 р. приблизно 758154 осіб із 198 країн було внесено до списку австралійських студентів, в тому числі 5 тис. осіб, які отримують заохочувальну стипендію уряду Австралії [8]. Країна пропонує іноземним студентам приблизно 26 тис. курсів в більш ніж 1200 університетах, коледжах і школах. Найбільш популярними напрямками освіти є отримання ступеня бакалавра та магістра, короткострокові курси та інтенсивні курси англійської мови. Зауважимо, що 75\% закордонних студентів $€$ вихідцями із країн Азії, але країни Середнього Сходу, Південної Америки й Африки також є джерелом іноземних студентів, чисельність яких швидко зростає. Іноземних студентів приваблюють високі стандарти освіти в Австралії, доброзичлива атмосфрера й диверсифріковане суспільство.

Школи навчання англійської мови в Австралії забезпечують широке розмаїття навчальних програм, починаючи 3 короткострокових курсів для студентів, які відвідують країну на канікулах, до формальних курсів 3 підготовки мовних фрахівців по всьому світу. Студенти приїжджають в Австра- лію вивчати англійську мову для академічних та практичних цілей або з особистих причин.

На австралійських вебсайтах оприлюднюється повна інфрормація щодо курсів, установ та можливостей, відкритих для іноземних студентів. Для комфрортного доступу вебсайти оформлюються на декількох мовах. Наприклад, в 2019 р., відповідно до даних організації «Міжнародна освіта в Австралії» (Australian Education International), найбільша кількість іноземних студентів прибула з таких країн: Китай (212 264), Індія (115 607), Непал (53 723) Бразилія (27 366) В'єтнам (26 050) [8].

Австралія забезпечує стипендії студентам з Азіатсько-Тихоокеанського регіону, в тому числі в рамках так званої «Винагороди за старанність», яка присуджується Міністерством освіти, зайнятості та трудових відносин і Відділом стипендій та нагород Австралії. Завдяки «Винагороді за старанність» для австралійців відкриваються можливості займатися дослідженнями, навчанням або профресійним розвитком закордоном [2, с. 140].

Завдяки давній традиції прийому студентів 3-за кордону в Австралії відпрацьовані декілька схем, які дозволяють гарантовано вступити до потрібного закладу вищої освіти. Наприклад, одна 3 них пропонує інтенсивне навчання в рамках дипломної річної програми 3 переходом на другий курс університету відразу після її закінчення. Для випускників шкіл, які добре володіють англійською мовою, при університетах відкриті підготовчі відділення. Процедура прийому студентів максимально прискорена і спрощена. Вартість навчання в Австралії на 35-40\% менша, ніж у Європі та у Сполучених Штатах Америки. Більшість австралійських навчальних програм за якістю нічим не поступається англійським, американським і канадським аналогам [2].

Висновки. Отже, на основі вищевикладеного, можна зробити висновок про те, що система вищої освіти Австралії пройшла шлях від декількох невеликих університетів до складної системи, яка складається із 40 університетів та 350 коледжів. Вищій освіті Австралії, яка базувалась на принципах британської системи, притаманні висока якість викладання, інтернаціоналізація, гуманізація освіти, самостійність студентів та значний акцент на наукові дослідження. Вважаємо, що перспективою подальшого вивчення $€$ проблема інтернаціоналізації вищої освіти Австралії, оскільки країна $€$ одним із лідерів в наданні освітніх послуг іноземним громадянам.

\section{БІБЛІОГРАФІЧНИЙ СПИСОК:}

1. Зарубіжна система вищої освіти : навч. посібн. / авт.-упоряд. М. Гагарін. Умань : ВПЦ «Візаві», 2017. $102 \mathrm{c}$

2. Мосолова О. Система образования и подготовки кадров в Австралии. Юго-восточная Азия: актуальные проблемы развития. 2015. № 27. С. 134-142. 
3. Barrigos R. The neoliberal transformation of higher education [Електронний ресурс]. Режим доступу : https://marxistleftreview.org/articles/the-neoliberaltransformation-of-higher-education/.

4. Harman G. Internationalization of Australian Higher Education: A Critical Review of Literature and Research / [Електронний ресурс]. Режим доступу : https://federation.edu.au/_data/assets/pdf_file/0013/ 221251/6-Internationalization-Harman.pdf.

5. Higher Education in Australia. A review of reviews from Dawkins to today. Higher Education Funding in Australia, Department of Education and Training. Canberra 2015. $39 \mathrm{p}$.
6. History of Higher Education in Australia [Електронний ресурс]. Режим доступу : https://www.k12academics.com/Higher\%20 Education\%20Worldwide/.

7. Higher\%20Education\%20in\%20Australia/historyhigher-education-australia.

8. Pattison P. Standards And Quality In Australian Higher Education / Pattison P. Visions For Australian Tertiary Education Melbourne. The University of Melbourne , 2017. February. C. 101-110.

9. Student Numbers at Australian Universities [Електронний ресурс]. Режим доступу https://www.australianuniversities.com.au/directory/ student-numbers. 